\title{
In-Stream Variability of Litter Breakdown and Consequences on Environmental Monitoring
}

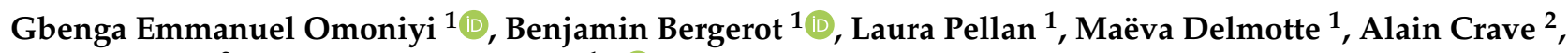 \\ Joris Heyman ${ }^{2}$ and Christophe Piscart $1, *$ (D)
}

1 Univ Rennes, CNRS, ECOBIO UMR 6553, F-35000 Rennes, France; gbenga.omoniyi@univ-rennes1.fr (G.E.O.); benjamin.bergerot@univ-rennes1.fr (B.B.); lorapellan@gmail.com (L.P.); delmotte.maeva@aesn.fr (M.D.)

2 Univ Rennes, CNRS Géosciences Rennes, UMR 6118, F-35000 Rennes, France; alain.crave@univ-rennes1.fr (A.C.); joris.heyman@univ-rennes1.fr (J.H.)

* Correspondence: christophe.piscart@univ-rennes1.fr; Tel.: +33-(0)2-23-23-54-39

check for updates

Citation: Omoniyi, G.E.; Bergerot, B.; Pellan, L.; Delmotte, M.; Crave, A.; Heyman, J.; Piscart, C. In-Stream Variability of Litter Breakdown and Consequences on Environmental Monitoring. Water 2021, 13, 2246. https://doi.org/10.3390/w13162246

Academic Editor: Geta Risnoveanu

Received: 19 July 2021

Accepted: 16 August 2021

Published: 17 August 2021

Publisher's Note: MDPI stays neutral with regard to jurisdictional claims in published maps and institutional affiliations.

Copyright: (c) 2021 by the authors. Licensee MDPI, Basel, Switzerland. This article is an open access article distributed under the terms and conditions of the Creative Commons Attribution (CC BY) license (https:// creativecommons.org/licenses/by/ $4.0 /)$.

\begin{abstract}
Energy derived from leaf litter decomposition fuels food webs in forested streams. However, the natural spatial variability of the decomposition rate of leaf litter and the relative contributions of its drivers are poorly known at the local scale. This study aims to determine the natural instream variability of leaf litter decomposition rates in successive riffles and to quantify the factors involved in this key ecosystem process at the local scale. Experiments were conducted on six successive riffles in nine streams in north-western France to monitor the decomposition rate in fine (microbial decomposition, $k f$ ) and coarse (total decomposition, $k c$ ) mesh bags. We recorded $30 \pm 2 \%$ (mean \pm S.E.) variation in $k c$ among riffles and $43 \pm 4 \%$ among streams. $k f$ variability was $15 \pm 1 \%$ among riffles and $20 \pm 3 \%$ among streams. However, in-stream variability was higher than between-stream variability in four of the nine streams. Streambed roughness was negatively related to decomposition and was the most important factor for both total and microbial decomposition. Our study shows that the natural variability of the decomposition rate resulting from the local morphological conditions of habitats could be very important and should be taken into consideration in studies using leaf litter assays as a bio-indicator of anthropogenic impacts in streams.
\end{abstract}

Keywords: organic matter recycling; natural variability; leaf litter decomposition; geomorphological factors

\section{Introduction}

Energy deficit resulting from canopy shading in forested streams is partly compensated by allochthonous inputs of leaf litter from riparian vegetation [1-4]. Energy from leaf litter is incorporated following a sequence of interdependent processes that include leaching by flowing water, conditioning by aquatic microbes, physical abrasion, and consumption by macroinvertebrate shredders [5]. Colonization of litter by microorganisms reduces its toughness [6-8], increases leaf quality and nutrient content [9], and thereby litter palatability for macroinvertebrate shredders [7,10,11]. Macroinvertebrate shredders turn coarse particulate matter into fine particulate matter and dissolved organic matter that is later consumed by other aquatic invertebrates [10,12-14] and microbes [15,16].

Litter breakdown has been proposed [17] and widely used as an indicator tool of the ecological status of streams with evident results [18-27] because of the relative ease of implementing the leaf litter assay and the fundamental role leaf litter plays in the trophic structure of headwater streams. Nevertheless, litter breakdown is a complex process influenced by both internal (in-stream) and external (climatic and anthropogenic) environmental factors. This makes it difficult to disentangle the effects of anthropogenic stressors from those of natural variability in impacted systems [17]. In the latter study, authors suggested standardization of the assessment procedure and a possible stream classification and/or comparative approach as means of untangling the effects of internal 
environmental factors from those of anthropogenic stressors. However, these factors also react at different temporal and spatial scales (mesohabitat, reach, catchment, and region) [28-31], hence, it is important to determine not only the factors involved but also the scale at which they respond [28]. At the global and regional scales, climatic and geological factors are very important for water quality and hydrological conditions [32]. For instance, previous research has found that the decomposition rate is low and mostly driven by microbial activity in tropical streams with warmer waters where invertebrate detritivores are less diverse [33] than in temperate streams. Furthermore, nutrient concentrations resulting from geological formation influence the heterotrophic microbial biomass available for decomposition [34]. At the catchment scale, where climatic and geological conditions are more homogeneous, stream size (or stream order), land use and other related factors impact litter breakdown rates $[23,29,35]$. The range of habitats at the reach scale and the different substrate structures and sizes influence the litter trapping efficiency of those mesohabitats [36,37]. At the riffle mesohabitat scale, flow [38] could combine synergistically with substrate roughness to increase physical abrasion [39] and thereby increase the litter breakdown rate. Finally, at the litter patch scale, composition of leaves [7] and leaf litter mixing [40] may deeply change the breakdown rate.

While the factors at play in the ecosystem function are hierarchical, the actual sites where these processes take place are the mesohabitats, and local factors may drive the processes at this very fine scale. Some authors hence chose the riffle as the primary habitat to examine the spatial trend of decomposition rates across nested habitats [29]. However, and surprisingly to the best of our knowledge, very few studies have addressed the natural instream variability, and no studies focused on riffles.

In this context, our study aimed to quantify the natural variability of decomposition rates over the few meters corresponding to the distance between successive riffles. Significant in-stream variability may indeed strongly impair the efficiency of monitoring programs using litter decomposition as a bio-indicator. We hence selected sites in similar and weakly altered watersheds to standardize external environmental factors including anthropogenic stressors (i) to determine the natural in-stream variability of decomposition rates at the local scale, (ii) quantify the interacting factors that drive the process, and (iii) compare the magnitude of this variability with the between-stream variability.

Our experiment was conducted in nine streams and six successive riffles per stream, all located in natural watersheds. We expected riffles located within any given watershed over a short distance (i.e., few meters) to be identical in terms of water chemistry and temperature, but their hydrological conditions could strongly vary according to other physical factors (e.g., stream slope and width). Based on this physical heterogeneity, we firstly predicted that in-stream variability in small heterogeneous streams may be in the same range as between-stream variability [41]. Secondly, we predicted that the in-stream variability of the rates of decomposition by microorganisms would be higher than the rates of decomposition by invertebrates. Microbial activities in streams are indeed mediated at the microhabitat scale, while the activities of macroinvertebrates are less impacted at this scale because of their ability to swim or drift over few meters, which may reduce the spatial heterogeneity at the reach scale [22]. Lastly, we predicted that several physical factors mediating the variability of litter breakdown would be the same for invertebrate litter breakdown as in microbial decomposition. Though microorganism activities are mainly regulated by sediment organic content, sediment size, nutrient content and temperature [22,23], the distribution of these abiotic factors and invertebrate communities are both influenced by flow, among other factors [42].

\section{Materials and Methods}

\subsection{Study Sites}

A leaf litter decomposition experiment was carried out in nine streams (Figure 1) ranging from the 1st to the 3rd orders in Strahler's classification and located in northwestern France. We established six successive riffles on each stream, selected in the 
same reach and a few meters apart in the first-order streams, and located up to $30 \mathrm{~m}$ apart in the third-order streams. The sites were selected to standardize anthropogenic stressors (nutrient loading, land use, canopy cover, industrial and domestic seepage, etc.). Consequently, the riffles were sited in natural watersheds without dense canopy cover by riparian trees and were similar in terms of physicochemical parameters such as temperature, $\mathrm{pH}$, conductivity, and oxygen saturation (Table 1), and also had similar riparian vegetation mainly composed of deciduous tree species (oak, alder, and chestnut) and grassland to avoid any strong effect of these factors. The riffles were examined visually to ensure that the stretch of microhabitats was as highly diverse as possible and adequately representative of the streams.

b)

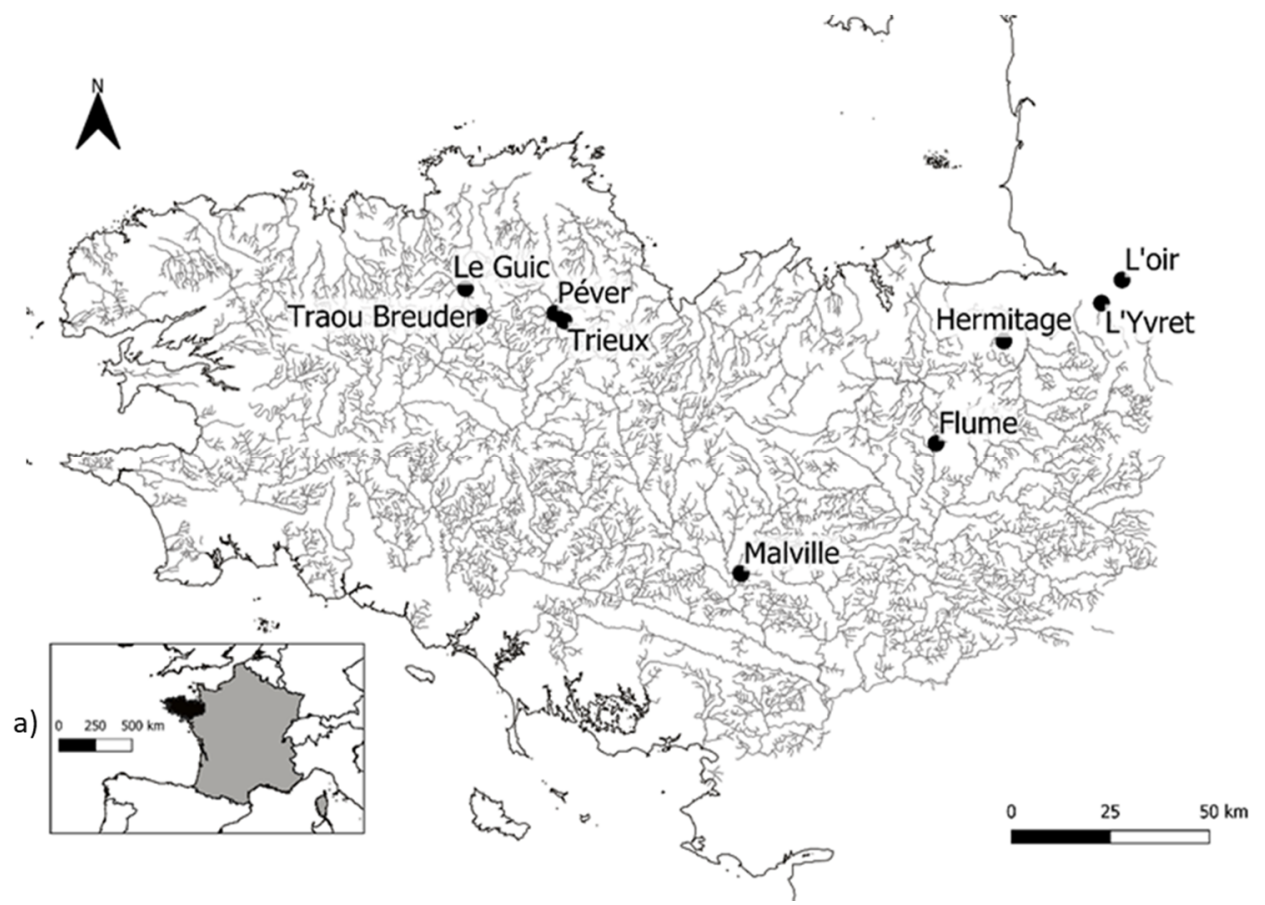

Figure 1. Maps of (a) France with administrative regions, and (b) the study area showing the localizations of the nine streams. Black lines represent stream networks.

Table 1. Mean $( \pm S E)$ values of the physico-chemical characteristics of the nine streams (number between brackets corresponds to the stream order) during the leaf litter experiment.

\begin{tabular}{ccccc}
\hline Streams (Strahler Order) & $\mathbf{O}_{\mathbf{2}}$ Saturation (\%) & Temperature $\left({ }^{\circ} \mathbf{C}\right)$ & $\mathbf{p H}$ & Electrical Conductivity $(\boldsymbol{\mu s} / \mathbf{c m})$ \\
\hline Trieux (3) & $99.3 \pm 3.0$ & $7.8 \pm 0.5$ & $8.4 \pm 0.8$ & $205 \pm 3$ \\
Hermitage (1) & $93.4 \pm 0$ & $13.2 \pm 0.3$ & $9.3 \pm 1.0$ & $152 \pm 2$ \\
Le Guic (3) & $94.2 \pm 0.3$ & $9.7 \pm 0.7$ & $8.7 \pm 1.8$ & $113 \pm 4$ \\
Traou Breuder (1) & $90.5 \pm 0$ & $10.8 \pm 0$ & $8.7 \pm 1.1$ & $178 \pm 1$ \\
Malville (2) & $88.2 \pm 7.6$ & $9.9 \pm 0.3$ & $7.9 \pm 0.5$ & $305 \pm 43$ \\
L'oir (2) & $100.4 \pm 0.9$ & $9.2 \pm 0.5$ & $7.2 \pm 0.3$ & $194 \pm 8$ \\
Flume (2) & $113.8 \pm 10.6$ & $11.9 \pm 1.0$ & $8.9 \pm 1.1$ & $356 \pm 18$ \\
Péver (2) & $92.4 \pm 0$ & $9.4 \pm 0.6$ & $9.0 \pm 1.5$ & $233 \pm 0$ \\
L'Yvret (1) & $97.5 \pm 0$ & $10.0 \pm 0.4$ & $7.5 \pm 0.3$ & $240 \pm 5$ \\
\hline
\end{tabular}

\subsection{Litter Decomposition}

Freshly abscised alder leaves (Alnus glutinosa (L.) Gaertn) collected between midNovember and mid-December 2018 were air-dried at room temperature in the laboratory. Alnus glutinosa was selected because it could be considered as a good quality resources compared to species such as Quercus or Fagus and is particularly present in wetlands and 
near streams [8,11]. Known weights Wo $(2.06 \pm 0.001 \mathrm{~g})$ of dried leaves were remoistened and enclosed in coarse-mesh $(5 \mathrm{~mm}$ mesh size $) 10 \times 10 \mathrm{~cm}$ plastic bags or fine-mesh $(0.5 \mathrm{~mm}$ mesh size) $10 \times 10 \mathrm{~cm}$ nylon bags. The coarse bags allow access to shredders and microbes, while the fine bags only allow access to microbes. This way, total decomposition $(k c)$ and contribution from microbial conditioning and other background variables such as leaching, physical abrasion, sediment loads and other hydraulic factors $(k f$, later referred as microbial decomposition) can be estimated, respectively [22]. In total, 540 bags ( 2 types of bags $\times$ 5 replicates $\times 6$ riffles $\times 9$ streams) were exposed at the same dates in all the sites in the spring of 2019. The bags were staked at random locations throughout each riffle in pairs of coarse and fine mesh bags to the stream bed using an inverted J-shaped iron rod. The anchored edges of the two bags were placed at a right angle to each other so that the bags did not overlap but rather rested on the substrate. The bags were retrieved after 14 days, transported, and sealed in zip-lock bags in a box for storage in the laboratory at $-20{ }^{\circ} \mathrm{C}$ for further treatment.

In the laboratory, the remaining leaf material was thawed, gently rinsed with tap water to remove any accumulated debris and mud. The leaf residue was air-dried to a constant weight (generally 3 days at room temperature), weighed, and incinerated at $550{ }^{\circ} \mathrm{C}$ for $4 \mathrm{~h}$ to obtain the Ash Free Dry Mass, AFDM (Wt). Decomposition rates, $k c$ (coarse-mesh bags), and $k f$ (fine-mesh bags) were calculated using the negative exponential decay model as shown in Equation (1) [1]:

$$
k=[\ln (\mathrm{Wt} / \mathrm{Wo})] / t
$$

where $t$ is the exposure time in days.

The litter fragmentation rate $\lambda \mathrm{F}$ was calculated from values of $k c$ and $k f$ according to Lecerf [43] (Equation (2)):

$$
\lambda \mathrm{F}=k c-\frac{k f-k c}{\ln (k f)-\ln (k c)}
$$

We also computed the ratio $k f: k c$ as a descriptor of the relative contributions of microorganisms to the total decomposition rate and the ratio $\lambda \mathrm{F}: k c$ as a descriptor of the relative contributions of macroinvertebrates in the total decomposition rate.

\subsection{Morphological Factors}

Stream width was estimated using the mean values of four transects established on each riffle. Width represents the distance between the tops of the left and right banks. Depending on the width of each transect, at least 12 points of equal interval were established on each transect to estimate the mean water depth $(\mathrm{N} \geq 48)$. This measurement was repeated at each of the three visiting dates. We defined the depth-width ratio, a dimensionless factor, to avoid entering the two collinear factors in the same model [25]. For each of the 48 points, the water depth (i.e., the height between the surface of the water and the top of substrate) was measured $( \pm 5 \mathrm{~mm}$ ) using a digital level (Leica Sprinter $250 \mathrm{~m}$ Digital Level) in order to estimate the magnitude of bed roughness. The substrate roughness was estimated as the standard deviation of the 48 measured water depth. Indeed, previous studies found that at low relative depths, the blocking of flow area by roughness elements is shown to be related to the standard deviation of local bed surface heights [44].

The slope of each riffle was also measured using a digital level (Leica Sprinter $250 \mathrm{~m}$ Digital Level) between the top of the riffle and the deepest part of the pool downstream riffle. We also estimated other physical factors such as shear stress as $\rho g h s$, where $\mathrm{h} \equiv$ mean depth, $\rho \equiv$ weight density of water $\left(1000 \mathrm{~kg} \mathrm{~m}^{-3}\right), \mathrm{g} \equiv$ gravity $\left(9.81 \mathrm{~m} \mathrm{~s}^{-2}\right)$, and $\mathrm{s} \equiv$ water slope.

Water depth was very low in most of the streams (generally less than $15 \mathrm{~cm}$ ) and turbulence was very high (minimum Reynolds' number 6300) so that the measurement of flow velocity with a velocimeter was not possible. Consequently, we shot short videos of the water flow to estimate the surface flow velocity on each riffle and at each visit. The videos were analyzed using TracTrac PTV software developed in our laboratory [45]. The program tracks every moving object on the water surface and provides its mean 
displacement in pixels per frame. Mean displacement was converted into mean velocity in meters per second by multiplying each measurement by the frame rate of the camera and by a video scale determined on each riffle.

\subsection{Macroinvertebrate Sampling}

Macroinvertebrate samples were collected using a Surber net sampler $\left(0.05 \mathrm{~m}^{2}\right.$ and $0.5 \mathrm{~mm}$ mesh size). Surber sampler is efficient for quantitative measurements and in catching cryptic species. Substrate composition in each riffle was assessed visually, and four replicate samples of macroinvertebrates representing substrate composition were taken from each riffle. The samples were fixed in $96 \%$ ethanol in situ. In the laboratory, macroinvertebrates were separated from other materials, and debris was discarded. Among macroinvertebrates, shredders (mostly amphipods, trichopteran, and plecopteran larvae) were determined according to Tachet et al. [46], and their abundance was enumerated at the species level.

\subsection{Statistical Analyses}

We performed a three-factor two-way nested ANOVA using decomposition rate as response variables, with riffles nested in streams and treatment (coarse and fine mesh bags) blocked within riffles to test the variability of decomposition rates among streams, riffles, and treatment. Coefficients of variation (CVs) computed either with the mean values $k c$ and $k f$ of each riffle (i.e., in-stream variability) or with the mean values $k c$ and $k f$ of each stream (i.e., between stream variability) were used to estimate the natural instream and between stream variabilities of leaf litter decomposition rates.

To analyze how physical factors measured at the riffle scale influence leaf litter $(k c$ and $k f$ ), generalized linear models (GLMs) were performed. The mean riffle values of $k c$ and $k f$ were the response variables, while the mean riffle values of the physical factors were the explanatory variables in models. To avoid having two collinear factors in the same model [25], we conducted a collinearity check of the predictors using Spearman's rank correlation. High collinearity was assumed for $r$ spearman $\geq 0.7$ [47]. Thus, GLMs with Gaussian family were run for both $k c$ and $k f$, with non-collinear physical factors as predictor variables. Model selection was performed using the step function in the lmer package [48]. The models with the lowest Akaike's information criterion (AIC) score were considered as the best-fit models, and the amount of accounted deviance (D2) was estimated using the Dsquared function in the modEva package [49].

All data analyses were performed using R software, version 3.6.2. [50].

\section{Results}

\subsection{In-Stream and Between-Stream Litter Breakdown Rates}

The nested ANOVA showed that the mean value of $k c\left(0.069 \pm 0.007 \mathrm{~g} \mathrm{day}^{-1}\right)$ was significantly higher (Table 2$)$ than the mean value of $k f\left(0.021 \pm 0.0004 \mathrm{~g} \mathrm{day}^{-1}\right)$. Similarly, the $\mathrm{CV}$ of $k c$ was significantly higher than the $\mathrm{CV}$ of $k f\left(\mathrm{~F}_{1106}=45.07, p<0.001\right)$.

Table 2. Results of the nested ANOVA testing decomposition rate according to the streams, riffles nested within streams; treatments (coarse and fine mesh bags) within riffles.

\begin{tabular}{lccccc}
\hline & Degree of Freedom & Sum of Squares & Mean Squares & F & $p$ \\
\hline Stream & 8 & 0.34 & 0.04 & 41.85 & $<0.001$ \\
Riffle & 5 & 0.005 & 0.001 & 1.04 & 0.395 \\
Stream | Riffle & 40 & 0.10 & 0.002 & 2.45 & $<0.001$ \\
Riffle | Treatment & 6 & 0.28 & 0.05 & 16.94 & $<0.001$ \\
\hline
\end{tabular}

Decomposition rate significantly varied among riffles nested with streams (Table 2), with $k c$ which present a mean in-stream CV of $30 \pm 2 \%$ (Figure 2), and between streams (Table 2), with a mean between streams CV of $43 \pm 4 \%$. Moreover, the in-stream CV of $k c$ 
was higher than the between-stream CV in four of the nine streams (Péver, Guic, Trieux, and Flume) (Figure 2).

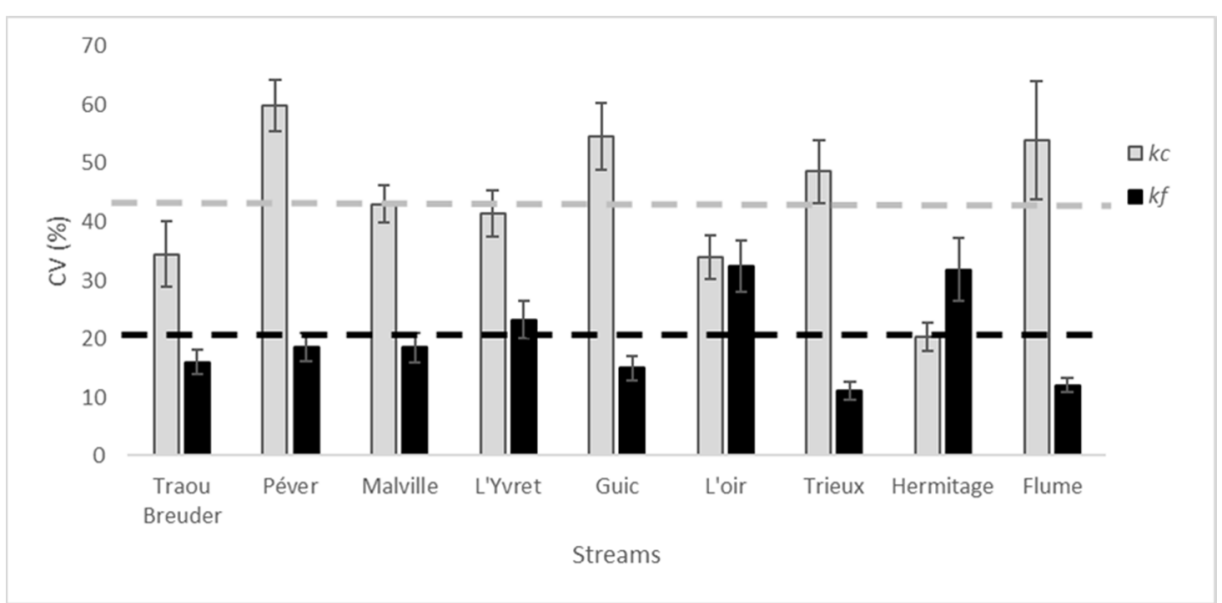

Figure 2. Mean values $( \pm \mathrm{SE})$ of total decomposition $(k c)$, and microbial decomposition $(k f)$ in each riffle for the 9 streams.

$k f$ was also significantly different between streams ( $C V=20 \pm 3 \%)$, and to a lesser extent among riffles ( $\mathrm{CV}=15 \pm 1 \%$ ) (Table 2).

The between-riffle variability of $k c$ was very high, and so was the decomposition rates among streams (Figure 3), whereas $k f$ variability was more similar within streams than it was among streams (Figure 3).

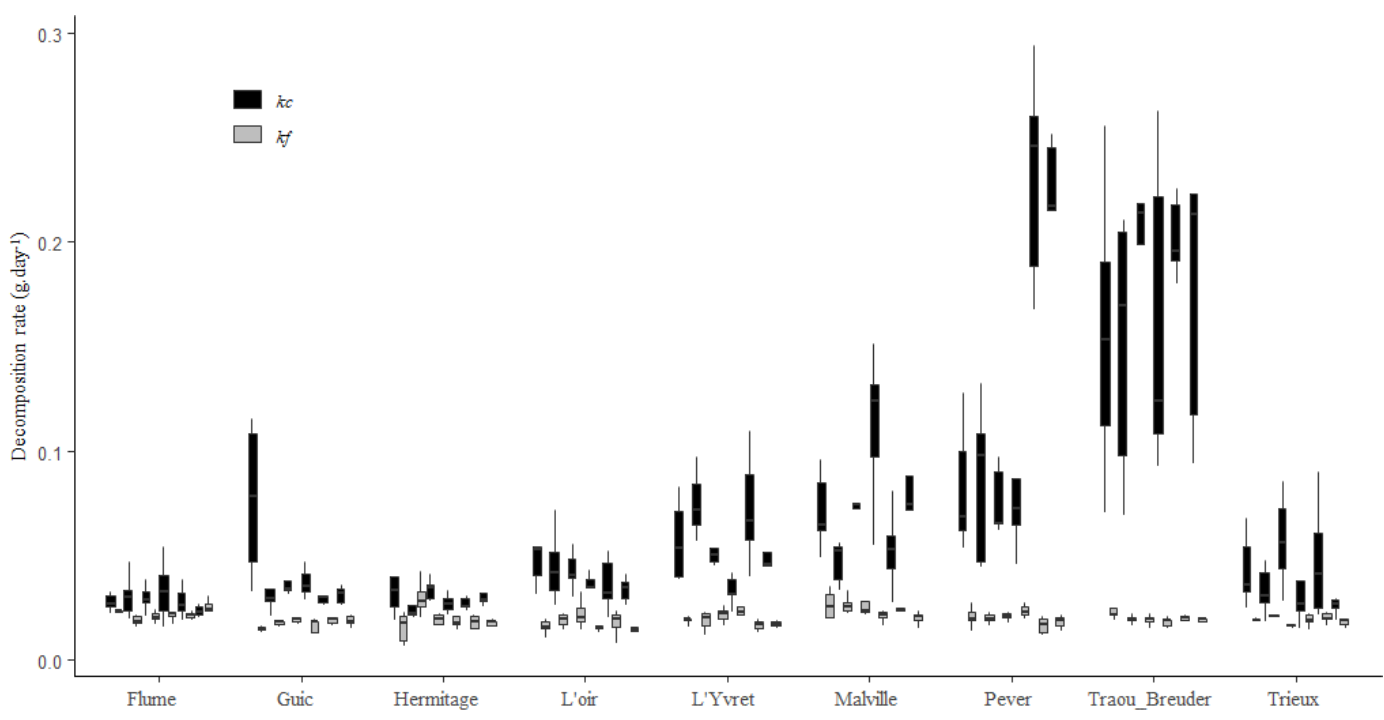

Figure 3. Mean $\pm \mathrm{SE}$ in-stream variability measured by the coefficients of variation (CVs) of $k c$ and $k f$ for the nine streams.

The ratio $k f: k c$ was higher than the ratio $\lambda \mathrm{F}: k c$ in five streams (Le Guic, L'oir, Trieux, Hermitage, and Flume Figure 4). This suggests that microbial activities in these streams contribute more to litter decomposition than invertebrate shredders. 


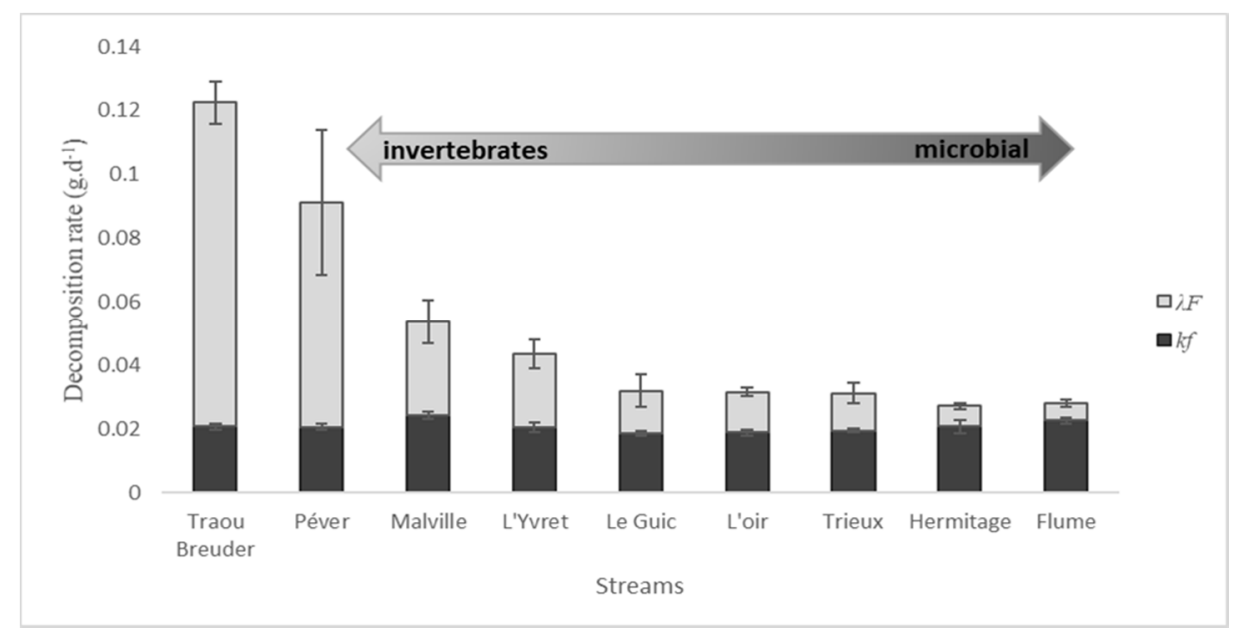

Figure 4. Mean \pm SE proportions of $k f$ and $\lambda F$ in total decomposition rate $(k c)$. Bars are ordered along the gradient of shredders' contribution to decomposition rates.

We recorded a total of 12,320 shredders comprising $86 \%$ of crustaceans (mainly Amphipods and few Isopods), 11\% of Plecoptera, 3\% of Trichoptera (mainly Limnephilidae), and less than $1 \%$ of tipulid Dipterans. There was a positive correlation between kc and shredder abundance $\left(\mathrm{r}\right.$ spearman $\left.=0.48, \mathrm{F1}_{106}=3.93, p<0.001\right)$.

\subsection{Physical Factors}

The mean values and CVs of physical factors are presented in Table 3. There was a high collinearity ( $\mathrm{r}$ spearman $\geq 0.7$ ) among physical factors (Table 4).

Table 3. Mean values ( \pm SE) and coefficient of variation $(\mathrm{CV})$ of morphological factors.

\begin{tabular}{|c|c|c|c|c|c|c|c|}
\hline Site & $\begin{array}{l}\text { Depth } \\
(\mathrm{cm})\end{array}$ & Slope & $\begin{array}{c}\text { Bankfull } \\
\text { Width }(\mathrm{cm})\end{array}$ & $\begin{array}{l}\text { Roughness } \\
\text { (cm) }\end{array}$ & $\begin{array}{l}\text { Flow Velocity } \\
\quad\left(\mathrm{m} \mathrm{s}^{-1}\right)\end{array}$ & Depth/Width & $\begin{array}{l}\text { Shear Stress } \\
\left(\mathrm{kg} \mathrm{m}^{-1} \mathrm{~s}^{-2}\right)\end{array}$ \\
\hline Traou Breuder & $4.7 \pm 0.3$ & $-0.01 \pm 0.001$ & $194 \pm 5$ & $2.9 \pm 0.3$ & $0.25 \pm 0.03$ & $0.02 \pm 0.001$ & $45.1 \pm 2.42$ \\
\hline CV (\%) & 13.0 & 30.5 & 6.2 & 27.7 & 27.6 & 14.1 & 13.2 \\
\hline Péver & $5.8 \pm 0.7$ & $-0.01 \pm 0.004$ & $308 \pm 19$ & $4.7 \pm 0.49$ & $0.26 \pm 0.04$ & $0.02 \pm 0.003$ & $56.1 \pm 6.8$ \\
\hline $\mathrm{CV}(\%)$ & 28.9 & 37.8 & 15.3 & 25.6 & 36.8 & 35.3 & 29.7 \\
\hline Malville & $10.7 \pm 0.9$ & $-0.002 \pm 0.01$ & $227 \pm 20$ & $4.0 \pm 0.4$ & $0.20 \pm 0.03$ & $0.05 \pm 0.01$ & $104 \pm 9.62$ \\
\hline CV $(\%)$ & 22.5 & 38.8 & 21.7 & 21.4 & 37.8 & 34.2 & 22.6 \\
\hline L'Yvret & $7.6 \pm 0.6$ & $-0.03 \pm 0.01$ & $322 \pm 31$ & $5.8 \pm 0.2$ & $0.11 \pm 0.04$ & $0.03 \pm 0.003$ & $73.0 \pm 5.9$ \\
\hline $\mathrm{CV}(\%)$ & 18.3 & 68.6 & 23.2 & 9.8 & 80.3 & 29.2 & 19.8 \\
\hline Le Guic & $48.7 \pm 3.1$ & $-0.003 \pm 0.002$ & $1157 \pm 55$ & $15.8 \pm 1.36$ & $0.25 \pm 0.02$ & $0.04 \pm 0.003$ & $476.3 \pm 29.9$ \\
\hline $\mathrm{CV}(\%)$ & 15.7 & 91.3 & 11.6 & 20.9 & 19.1 & 19.7 & 15.4 \\
\hline L'oir & $8.3 \pm 0.1$ & $-0.02 \pm 0.004$ & $233 \pm 4.5$ & $5.6 \pm 0.6$ & $0.27 \pm 0.06$ & $0.04 \pm 0.001$ & $80.3 \pm 1.1$ \\
\hline $\mathrm{CV}(\%)$ & 2.9 & 49.5 & 4.8 & 27.5 & 53.5 & 4.4 & 3.3 \\
\hline Trieux & $30.9 \pm 3.7$ & $-0.04 \pm 0.04$ & $1069 \pm 52$ & $14.1 \pm 1.2$ & $0.26 \pm 0.04$ & $0.03 \pm 0.004$ & $294.8 \pm 39.8$ \\
\hline $\mathrm{CV}(\%)$ & 29.1 & 209.5 & 11.9 & 21.1 & 32.6 & 32.6 & 33.0 \\
\hline Hermitage & $8.0 \pm 0.4$ & $-0.01 \pm 0.01$ & $254 \pm 17$ & $5.0 \pm 0.6$ & $0.35 \pm 0.03$ & $0.03 \pm 0.004$ & $77.7 \pm 4.2$ \\
\hline CV (\%) & 13.5 & 96.4 & 16.1 & 30.9 & 17.3 & 27.4 & 13.1 \\
\hline Flume & $4.0 \pm 0.5$ & $-0.03 \pm 0.01$ & $278 \pm 15$ & $4.0 \pm 0.6$ & $0.29 \pm 0.07$ & $0.01 \pm 0.001$ & $37.9 \pm 4.7$ \\
\hline CV $(\%)$ & 29.0 & 68.4 & 13.2 & 33.9 & 54.4 & 23.2 & 30.4 \\
\hline
\end{tabular}


Table 4. Spearman correlation coefficients ( $\mathrm{r}$ spearman $>0.7$ in bold) between morphological factors.

\begin{tabular}{|c|c|c|c|c|c|c|c|}
\hline & Depth & Slope & Bankfull Width & Roughness & Flow Velocity & Depth/Width & Shear Stress \\
\hline Depth & 1.00 & & & & & & \\
\hline Slope & -0.10 & 1.00 & & & & & \\
\hline $\begin{array}{l}\text { Bankfull } \\
\text { Width }\end{array}$ & 0.90 & 0.03 & 1.00 & & & & \\
\hline Roughness & 0.89 & 0.02 & 0.92 & 1.00 & & & \\
\hline Flow Velocity & -0.05 & -0.09 & -0.03 & 0.04 & 1.00 & & \\
\hline Depth/Width & 0.47 & -0.22 & 0.15 & 0.27 & -0.13 & 1.00 & \\
\hline Shear Stress & 0.99 & -0.15 & 0.90 & 0.89 & -0.05 & 0.47 & 1.00 \\
\hline
\end{tabular}

The GLMs for $k c$ and $k f$ included four factors (slope, roughness, flow velocity, and depth/width ratio) preselected based on the correlation coefficient. There were no significant differences in the AIC scores of the selection models for either $k c$ or $k f$, so the initial models containing the four preselected factors were retained as the best-fit models. $\mathrm{D}^{2}$ was 0.18 and 0.13 for $k c$ and $k f$, respectively. Among the morphological factors, only roughness was significantly related (negatively) to both $k c$ and $k f$ (Table 5).

Table 5. Results of the GLM of predictor variables on $k c$ and $k f$.

\begin{tabular}{lcccc}
\hline & $p$-Value $(\boldsymbol{k c})$ & Estimate $\pm \mathrm{SE}$ & $\boldsymbol{p}$-Value $(\boldsymbol{k f})$ & Estimate $\pm \mathrm{SE}$ \\
\hline Slope & 0.41 & $-0.20 \pm 0.24$ & 0.77 & $-0.004 \pm 0.01$ \\
Roughness & 0.03 & $-0.003 \pm 0.001$ & 0.01 & $-0.0002 \pm 0.0001$ \\
Flow velocity & 0.19 & $-0.04 \pm 0.03$ & 0.10 & $-0.003 \pm 0.002$ \\
Depth/Width & 0.58 & $-0.32 \pm 0.58$ & 0.96 & $-0.001 \pm 0.03$ \\
\hline
\end{tabular}

\section{Discussion}

\subsection{In-Stream and Between-Stream Variability of Decomposition Rates}

About in-stream and between-stream variabilities of decomposition rates, firstly we predicted that in-stream variability in small heterogeneous streams would be in the same range as between-stream variability [40]. Secondly, we predicted that the in-stream variability of the rates of decomposition by microorganisms would be higher than the rates of decomposition by invertebrates.

We highlighted that natural in-stream variability could be very high at the reach scale (in-stream CV up to $60 \%$ ) even if chemical factors remain stable along our selected watersheds. This result confirmed our first prediction that in-stream variability may be in the same order or even higher (in four of the nine streams in our case) than between-stream variability. Tonin et al. [51] suggested that such variability might be related to the canopy. They reported a higher variability of decomposition rates among reaches than among watersheds along a canopy cover gradient where the area covered by canopy decreased from stream reaches to watersheds. However, in streams that present similar and low canopy coverage, as is the case in our study, the variability of litter breakdown rates could also be very high. Other morphological factors at the riffle scale such as geomorphology could strongly drive the leaf litter decomposition process in such systems [29,31]. In bioassessment studies of impacted streams, this could constitute a natural source of variation difficult to account for and isolate from the variability due to anthropogenic stressors. One way to overcome this limitation could be a comparative approach of impacted versus unimpacted systems exhibiting similar natural characteristics, this condition being rarely encountered in most cases.

Secondly, we expected the variability of decomposition rates by microorganisms to be higher than the variability of the total litter breakdown rates. Microbial activities are indeed driven by local factors such as temperature [52], stream nutrient content [22,53,54], and fine sediment load [22]. While these factors are mostly temporal, they are largely spatially heterogeneous at the small, local scale at which this experiment was conducted. On the other hand, total litter breakdown is (in addition to microbial conditioning) mediated by 
heterogeneous hydraulic factors as well as variable geomorphological habitat parameters, thus making the process patchy within stream riffles $[55,56]$. However, and contrary to our expectations, we found higher variability of the total litter breakdown $(k c)$ than of microbial decomposition $(\mathrm{kf})$. Moreover, in our study sites, the proportion of microbial decomposition in total breakdown was also less variable than breakdown by invertebrate shredders $(\lambda F)$. The fact that the variability of the decomposition rate was mostly due to the variability of the invertebrate breakdown could be due to the patchiness of detritivore distribution $[57,58]$ and their sensitivity to hydromorphological parameters [59] that has been found in previous studies $[22,29,60,61]$. To explain the unexpected low microbial decomposition variability, one plausible reason for this may be the transport and distribution of fungal spores in streams by the water flow [62], resulting in the homogenization of leaf colonization by fungi. Secondly, the sites were mostly located in small natural watersheds, with minimal impacts of anthropogenic activities such that the chemical heterogeneity in terms of nutrient and sediment influx from the catchment basin was negligible. Therefore, our results are rather congruent with the observation of Colas et al. [25], who found that microorganisms react mainly at the catchment scale and less at the reach scale.

\subsection{Explaining Factors of Decomposition Rates}

We expected that physical factors mediating the variability of litter breakdown would be the same for invertebrate litter breakdown as in microbial decomposition. Accordingly, with this assumption, we found that the physical factors mediating breakdown rates were the same for the total breakdown and microbial decomposition rates. The physical factors describable in riffle mesohabitats are largely responsible for resource retention and distribution [63] and consequently for the community structure of macroinvertebrates and microbes in riffles $[29,64]$. Therefore, although the mechanisms and magnitude of interactions may not be the same, the hydromorphological factors influencing the two biotic agents (microbes and macroinvertebrates) of litter decomposition in streams appear to be the same. Although this is largely expected, it is noteworthy that only a small fraction of decomposition ( $<20 \%$ of deviation) can be explained by physical factors only. This suggests that invertebrate shredders likely remain the chief drivers of litter breakdown in streams. However, microorganisms, in half of our streams, mainly drove litter breakdown. Even though we did not measure the stream microbial load concentration, elevated microbial concentrations in streams are known drivers of litter decomposition [65-67].

More precisely, we found that among morphological factors, the most important factors for both total litter breakdown and microbial decomposition rates was the streambed roughness. The negative relationship between bed roughness and decomposition rates suggests a reduced decomposition rate when bed roughness is high. In lowland streams as in Brittany, and in natural conditions, bed roughness is positively correlated with particle size and in turn to flow velocity. When bed roughness increases, leaf litter stocks are easily and quickly washed off [63], and cannot serve as habitats and feeding resources for shredders. In the same vein, shredders are generally less adapted to high flow velocity and prefer low velocities [46]. Whereas in riffles with low bed roughness, substrates can be smaller and more similar in size (mainly sand and gravel). This condition could be more suitable for litter storage. According to Bovil et al. [37], reaches dominated by gravels retain the highest stocks of coarse organic particulate matter, while the lowest retention is found in reaches dominated by cobbles; these authors suggested that channel retentiveness does not increase with channel roughness. It could also be more suitable for conditioning by microbes and colonization by shredders, and explain a faster decomposition rate by both invertebrates and microbes. This realization could have profound implications for the management of headwater streams where leaf litter stocks from allochthonous sources occupy the base of the energy pyramid. Secondly, restoration efforts in impacted streams mostly involve activities that enhance habitat heterogeneity through the alteration of the geomorphological composition of the systems. Post-project assessments of restored streams largely relying on biodiversity as a bio-assessment tool. The sensitivity of leaf litter assay 
to geomorphological factors within the habitats, as observed in this study, suggests it can serve a complementary role as an integrative ecosystem-level bio-assessment tool in restored systems.

\section{Conclusions}

This study highlights that the natural in-stream variability of leaf litter breakdown rate could reach or even overreach the between-stream variability. Our study underscores the importance of local factors such as roughness as drivers of ecological processes and in turn overall ecosystem functioning. The sensitivity of this important ecological process to hydromorphological factors in stream mesohabitats has significant implications for stream management and the deployment of litter decomposition assays as a bio-indicator tool. One of the advantages of using ecosystem level processes such as leaf litter assays as a bio-assessment tool is that it provides an integrative measure of ecosystem integrity, but protocols need to be adapted to disentangle the influence of natural habitat conditions on decomposition rates from the effects of external environmental stressors. This is by no means an easy task in most cases. As a consequence, natural variability at the riffle scale must be taken into account in the assessment of anthropogenic impacts. One solution to integrate this very strong variability is to measure the breakdown rate on several successive riffles to obtain a good estimate of the mean values of the decomposition rates on each site, which is not the case in many studies. Further studies on the relationship between hydraulic factors, litter storage, and the presence of shredders are required to understand this complex relationship between morphological and biological factors explaining the spatial heterogeneity of the breakdown process.

\section{Patents}

This section is not mandatory but may be added if there are patents resulting from the work reported in this manuscript.

Author Contributions: Conceptualization, G.E.O., B.B., and C.P.; methodology, G.E.O., B.B., A.C., and C.P.; software, J.H.; formal analysis, G.E.O., B.B., and C.P.; investigation, all authors; resources, B.B. and C.P.; data curation, G.E.O., L.P. and M.D.; writing—original draft preparation, G.E.O., B.B. and C.P.; writing — review and editing, all; supervision, B.B. and C.P.; project administration, C.P. All authors have read and agreed to the published version of the manuscript.

Funding: This research was funded by the Brittany Region throughout the project BERCEAU (2019-2021). This work is part of the PhD Thesis of the first author who is granted by the Nigerian government throughout the TET fund (2019-2021).

Institutional Review Board Statement: Not applicable.

Informed Consent Statement: Not applicable.

Data Availability Statement: The data presented in this study are available on request from the corresponding author.

Conflicts of Interest: The authors declare no conflict of interest. The funders had no role in the design of the study; in the collection, analyses, or interpretation of data; in the writing of the manuscript, or in the decision to publish the results.

\section{References}

1. Petersen, P.C.; Cummins, K.W. Leaf processing in a woodland stream. Freshw. Biol. 1974, 4, 343-368. [CrossRef]

2. Gessner, M.; Chauvet, E.; Dobson, M. A Perspective on Leaf Litter Breakdown in Streams. Oikos 1999, 85, 377-384. [CrossRef]

3. Graça, M.A.S.; Ferreira, V.; Canhoto, C.; Encalada, A.C.; Guerrero-Bolano, F.; Wantzen, K.M.; Boyero, L. A conceptual model of litter breakdown in low order streams. Int. Rev. Hydrobiol. 2015, 100, 1-12. [CrossRef]

4. Collins, S.M.; Kohler, T.J.; Thomas, S.A.; Fetzer, W.W.; Flecker, A.S. The importance of terrestrial subsidies in stream food webs varies along a stream size gradient. Oikos 2015, 125, 674-685. [CrossRef]

5. Abelho, M. From litterfall to breakdown in streams: A review. Sci. World J. 2001, 1, 656-680. [CrossRef] [PubMed]

6. Assmann, C.; Rinke, K.; Nechwatal, J.; Von Elert, E. Consequences of the colonization of leaves by fungi and oomycetes for leaf consumption by a gammarid shredder. Freshw. Biol. 2011, 56, 839-852. [CrossRef] 
7. Foucreau, N.; Puijalon, S.; Hervant, F.; Piscart, C. Effect of leaf litter characteristics on leaf conditioning and on consumption by Gammarus pulex. Freshw. Biol. 2013, 58, 1672-1681. [CrossRef]

8. Foucreau, N.; Piscart, C.; Puijalon, S.; Hervant, F. Effect of climate-related change in vegetation on leaf litter consumption and energy storage by Gammarus pulex from continental or Mediterranean populations. PLoS ONE 2013, 8, e77242. [CrossRef]

9. Casotti, C.G.; Kiffer, W.P., Jr.; Costa, L.C.; Barbosa, P.; Moretti, M.S. The longer the conditioning, the better the quality? The effects of leaf conditioning time on aquatic hyphomycetes and performance of shredders in a tropical stream. Aquat. Ecol. 2019, 53, 163-178. [CrossRef]

10. Harrop, B.L.; Marks, J.C.; Watwood, M.E. Early bacterial and fungal colonization of leaf litter in Fossil Creek, Arizona. J. N. Am. Benthol. Soc. 2009, 28, 383-396. [CrossRef]

11. Santonja, M.; Pellan, L.; Piscart, C. Macroinvertebrate identity mediates the effects of litter quality and microbial conditioning on the leaf litter recycling in temperate streams. Ecol. Evol. 2018, 8, 2542-2553. [CrossRef]

12. Wetzel, R.G. Death, detritus, and energy flow in aquatic ecosystems. Freshw. Biol. 1995, 33, 83-89. [CrossRef]

13. Wallace, J.B.; Eggert, S.L.; Meyer, J.L.; Webster, J.R. Multiple trophic levels of a forest stream linked to terrestrial litter inputs. Science 1997, 277, 102-104. [CrossRef]

14. Pettit, N.E.; Davies, T.; Fellman, J.B.; Grierson, P.F.; Warfe, D.M.; Davies, P.M. Leaf litter chemistry, decomposition and assimilation by macroinvertebrates in two tropical streams. Hydrobiologia 2012, 680, 63-77. [CrossRef]

15. Hall, R.O.; Wallace, J.B.; Eggert, S.L. Organic matter flow in stream food webs with reduced detrital resource base. Ecology 2000, 81, 3445-3463. [CrossRef]

16. Joyce, P.; Wotton, R.S. Shredder fecal pellets as stores of allochthonous organic matter in streams. J. N. Am. Benthol. Soc. 2008, 27, 521-528. [CrossRef]

17. Gessner, M.O.; Chauvet, E. A case for using litter breakdown to assess functional stream integrity. Ecol. Appl. 2002, 12, 498-510. [CrossRef]

18. Gessner, M.O. Differences in processing dynamics of fresh and dried leaf litter in a stream ecosystem. Freshw. Biol. 1991, 26, 387-398. [CrossRef]

19. Robinson, C.T.; Gessner, M.O. Nutrient addition accelerates leaf breakdown in an alpine sprinkbrook. Oecologia 2000, 122, 258-263. [CrossRef] [PubMed]

20. Graça, M.A.S. The role of invertebrates on leaf litter decomposition in streams-A review. Inter. Rev. Hydrobiol. 2001, 86, 383-393. [CrossRef]

21. Niyogi, D.K.; Lewis, W.M., Jr.; McKnight, D.M. Litter breakdown in mountain streams affected by acid mine drainage: Biotic mediation of abiotic controls. Ecol. Appl. 2001, 11, 506-516. [CrossRef]

22. Piscart, C.; Genoel, R.; Dolédec, S.; Chauvet, E.; Marmonier, P. Effects of intense agricultural practices on heterotrophic processes in streams. Environ. Pollut. 2009, 157, 1011-1018. [CrossRef]

23. Piscart, C.; Navel, S.; Maazouzi, C.; Montuelle, B.; Cornut, J.; Mermillod-Blondin, F.; Chatelliers, M.C.; Simon, L.; Marmonier, P. Leaf litter recycling in benthic and hyporheic layers in agricultural streams with different types of land use. Sci. Total Environ. 2011, 409, 4373-4380. [CrossRef]

24. Tant, C.J.; Rosemond, A.D.; Helton, A.M.; First, M.R. Nutrient enrichment alters the magnitude and timing of fungal, bacterial, and detritivore contributions to litter breakdown. Freshw. Sci. 2015, 34, 1259-1271. [CrossRef]

25. Colas, F.; Baudoin, J.M.; Gob, F.; Tamisier, V.; Valette, L.; Kreutzenberger, K.; Lambrigot, D.; Chauvet, E. Scale dependency in the morphological control of a stream ecosystem functioning. Water Res. 2017, 115, 60-73. [CrossRef]

26. Wootton, A.; Pearson, R.G.; Boyero, L. Patterns of flow, leaf litter and shredder abundance in a tropical stream. Hydrobiologia 2018, 826, 353-365. [CrossRef]

27. Mlambo, M.C.; Paavola, R.; Fritze, H.; Louhi, P.; Muotka, T. Leaf litter decomposition and decomposer communities in streams affected by intensive forest biomass removal. Ecol. Indic. 2019, 101, 364-372. [CrossRef]

28. Royer, T.V.; Minshall, G.W. Controls on leaf processing in streams from spatial-scaling and hierarchical perspectives. J. N. Am. Benthol. Soc. 2003, 22, 353-358. [CrossRef]

29. Tiegs, S.D.; Akinwole, P.O.; Gessner, M.O. Litter decomposition across multiple spatial scales in stream networks. Oecologia 2009, 161, 343-351. [CrossRef] [PubMed]

30. Boyero, L.; Pearson, R.G.; Hui, C.; Gessner, M.O.; Pérez, J.; Alexandrou, M.A.; Graça, M.A.S.; Cardinale, B.J.; Albariño, R.J.; Arunachalam, M.; et al. Biotic and abiotic variables influencing plant litter breakdown in streams: A global study. Proc. R. Soc. B. 2016, 283, 1-10. [CrossRef]

31. Tiegs, S.D.; Costello, D.M.; Isken, M.W.; Woodward, G.; McIntyre, P.B.; Gessner, M.O.; Chauvet, E.; Griffiths, N.A.; Flecker, A.S.; Acuña, V.; et al. Global patterns and drivers of ecosystem functioning in rivers and riparian zones. Sci. Adv. 2019, 5, eaav0486. [CrossRef] [PubMed]

32. Chauvet, E.; Ferreira, V.; Giller, P.S.; McKie, B.G.; Tiegs, S.D.; Woodward, G.; Elosegi, A.; Dobson, M.; Fleituch, T.; Graça, M.A.S.; et al. Litter decomposition as an indicator of stream ecosystem functioning at local-to-continental scales: Insights from the European RivFunction project. Adv. Ecol. Res. 2016, 55, 99-182.

33. Boyero, L.; Pearson, R.G.; Dudgeon, D.; Graça, M.A.S.; Gessner, M.O.; Albariño, R.J.; Ferreira, V.; Yule, C.M.; Boulton, A.J.; Arunachalam, M.; et al. Global distribution of a key trophic guild contrasts with common latitudinal diversity patterns. Ecology 2011, 92, 1839-1848. [CrossRef] [PubMed] 
34. Reisinger, A.J.; Tank, J.L.; Dee, M.M. Regional and seasonal variation in nutrient limitation of river biofilms. Freshw. Sci. 2016, 35, 474-489. [CrossRef]

35. Meybeck, M. Carbon, nitrogen, and phosphorus transport by world rivers. Am. J. Sci. 1982, 282, 401-450. [CrossRef]

36. Hoover, T.M.; Marczak, L.B.; Richardson, J.S.; Yonemitsu, N. Transport and settlement of organic matter in small streams. Freshw. Biol. 2010, 55, 436-449. [CrossRef]

37. Bovill, W.D.; Downes, B.J.; Lake, P.S. A novel method reveals how channel retentiveness and stocks of detritus (CPOM) vary among streams differing in bed roughness. Freshw. Biol. 2020, 65, 1313-1324. [CrossRef]

38. Northington, M.R.; Webster, R.J. Experimental reductions in stream flow alters litter processing and consumer subsidies in headwater streams. Freshw. Biol. 2017, 62, 737-750. [CrossRef]

39. Dobson, M.; Hildrew, G.A.; Ibbotson, A.; Garthwaite, J. Enhancing litter retention in streams: Do altered hydraulics and habitat area confound field experiments? Freshw. Biol. 1992, 28, 71-79. [CrossRef]

40. Santonja, M.; Rodríguez-Pérez, H.; Le Bris, N.; Piscart, C. Leaf nutrients and macroinvertebrates control litter mixing effects on decomposition in temperate streams. Ecosystems 2020, 23, 400-416. [CrossRef]

41. Rezende, R.S.; Petrucio, M.M.; Gonçalves, J.F., Jr. The effects of spatial scale on breakdown of leaves in a tropical watershed. PLoS ONE 2014, 9, e97072. [CrossRef]

42. Bastias, E.; Bolivar, M.; Ribot, M.; Peipoch, M.; Thomas, S.A.; Sabater, F.; Marti, E. Spatial heterogeneity in water velocity drives leaf litter dynamics in streams. Freshw. Biol. 2020, 65, 435-445. [CrossRef]

43. Lecerf, A. Methods for estimating the effects of litterbag mesh size on decomposition. Ecol. Model. 2017, 362, 65-68. [CrossRef]

44. Smart, G.; Aberle, J.; Duncan, M.; Walsh, J. Measurement and analysis of alluvial bed roughness. J. Hydraul. Res. 2004, 42, 227-237. [CrossRef]

45. Heyman, J. TracTrac: A fast multi-object tracking algorithm for motion estimation. Comp. Geosci. 2019, 128, 11-18. [CrossRef]

46. Tachet, H.; Richoux, P.; Bournaud, M.; Usseglio-Polatera, P. Invertébrés d'eau Douce: Systématique, Biologie et Écologie; CNRS edition: Paris, France, 2000; 607p.

47. Dormann, C.F.; Elith, J.; Bacher, S.; Buchmann, C.; Carl, G.; Carré, G.; Marquéz, J.R.G.; Gruber, B.; Lafourcade, B.; Leitão, P.J.; et al. Collinearity: A review of methods to deal with it and a simulation study evaluating their performance. Ecograpraphy 2013, 36, 27-46. [CrossRef]

48. Kuznetsova, A.; Brockhoff, P.B.; Christensen, R.H.B. lmerTest Package: Tests in Linear Mixed Effects Models. J. Stat. Softw. 2017, 82, 1-26. [CrossRef]

49. Barbosa, A.M.; Real, R.; Munoz, A.R.; Brown, J.A. New measures for assessing model equilibrium and prediction mismatch in species distribution models. Divers. Distrib. 2015, 19, 1333-1338. [CrossRef]

50. R Core Team. R: A Language and Environment for Statistical Computing; R Foundation for Statistical Computing: Vienna, Austria, 2019.

51. Tonin, A.M.; Hepp, L.U.; Gonçalves, J.F., Jr. Spatial variability of plant litter decomposition in stream networks: From litter bags to watersheds. Ecosystems 2017, 21, 567-581. [CrossRef]

52. Suberkropp, K.; Weyers, H.S. Application of fungal and bacterial production methodologies to decomposing leaves in streams. Appl. Environ. Microbiol. 1996, 62, 1610-1615. [CrossRef]

53. Chamier, A.C. Water chemistry. In The Ecology of Aquatic Hyphomycetes; Barlocher, F., Ed.; Springer: Berlin, Germany, 1992; Volume 9, pp. 118-134.

54. Suberkropp, K.; Chauvet, E. Regulation of leaf breakdown by fungi in streams: Influences of water chemistry. Ecology 1995, 76, 1433-1445. [CrossRef]

55. Wright, K.K.; Li, J.L. From continua to patches: Examining stream community structure over large environmental gradients. Can. J. Fish. Aquat. Sci. 2002, 59, 1404-1417. [CrossRef]

56. Haapala, A.; Muotka, T.; Laasonen, P. Distribution of benthic macroinvertebrates and leaf litter in relation to streambed retentivity: Implications for headwater stream restoration. Boreal Environ. Res. 2003, 8, 19-30.

57. Boyero, L. Multiscale patterns of spatial variation of stream macroinvertebrate communities. Ecol. Res. 2003, 18, 365-379. [CrossRef]

58. Boyero, L.; Bosch, J. Multiscale spatial variation of stone recolonization by macroinvertebrates in a Costa Rican stream. J. Tropi. Ecol. 2004, 20, 85-95. [CrossRef]

59. Downes, B.J.; Lake, P.S.; Schreiber, E.S.G.; Glaister, A. Habitat structure, resources and diversity: The separate effects of surface roughness and macroalgae on stream invertebrates. Oecologia 2000, 123, 569-581. [CrossRef] [PubMed]

60. Murphy, J.F.; Giller, P.S.; Horan, M.A. Spatial scale and the aggregation of stream macroinvertebrates associated with leaf packs. Freshw. Biol. 1998, 39, 325-337. [CrossRef]

61. Abos, C.P.; Lepori, F.; McKie, B.G.; Malmqvist, B. Aggregation among resource patches can promote coexistence in stream-living shredders. Freshw. Biol. 2006, 51, 545-553. [CrossRef]

62. Bärlocher, F. The Ecology of Aquatic Hyphomycetes; Ecological Studies; Springer: Berlin/Heidelberg, Germany, 2012; 239p.

63. Larranaga, S.; Diez, J.S.; Elosegi, A.; Pozo, J. Leaf retention in streams of the Aguera basin (northern Spain). Aquat. Sci. 2003, 65, 158-166. [CrossRef]

64. Cummins, K.W.; Wilzbach, M.A.; Gates, D.M.; Perry, J.B.; Taliaferro, W.B. Shredders and riparian vegetation. BioScience 1989, 39, 24-30. [CrossRef] 
65. Gulis, V.; Suberkropp, K. Leaf litter decomposition and microbial activity in nutrient-enriched and unaltered reaches of a headwater stream. Freshw. Biol. 2003, 48, 123-134. [CrossRef]

66. Kuehn, K.A.; Ohsowski, B.M.; Francoeur, S.N.; Neely, R.K. Contributions of fungi to carbon flow and nutrient recycling from standing dead Typha angustifolia leaf litter in a temperate freshwater marsh. Limnol. Oceanogr. 2011, 56, 529-539. [CrossRef]

67. Santschi, F.; Gounand, I.; Harvey, E.; Altermatt, F. Leaf litter diversity and structure of microbial decomposer communities modulate litter decomposition in aquatic systems. Funct. Ecol. 2018, 32, 522-532. [CrossRef] 